\title{
LEARNING INDONESIAN LANGUAGE IN THE TIME OF THE COVID-19 PANDEMIC
}

\author{
Cecep Wahyu Hoerudin \\ UIN Sunan Gunung Djati, Bandung \\ Email: cecepwahyu@uinsgd.ac.id
}

\begin{abstract}
During the Covid-19 pandemic, the learning process is carried out using established regulations. Through this regulation, the implementation of Indonesian language learning is carried out using Distance Learning. This study then tries to see how the implementation of Indonesian language learning occurs during the Covid-19 pandemic. This research will be carried out using a qualitative approach using previous studies and research data. The results of this study found that Indonesian language learning had not been implemented optimally during the pandemic. Then the understanding of teachers and other teachers is still lacking in the emergency curriculum. Finally, the achievement of learning outcomes during the pandemic found that students' skills in writing texts were still lacking.
\end{abstract}

Keywords: Indonesian Language Learning, Emergency Curriculum, Covid-19 Pandemic.

\section{A. INTRODUCTION}

The implementation of Indonesian language learning during the COVID-19 pandemic refers to the regulations jointly determined by the four Ministers contained in the Decree of the Four Ministers regarding the implementation of learning during the COVID-19 pandemic. In line with that, the Ministry of Religion specifically issued guidelines on learning during the COVID-19 pandemic, which is called the Emergency Curriculum (Al Arif, 2017). Based on these two regulations, Indonesian language learning is carried out from home, known as Distance Learning (PJJ). The form of learning is carried out with three strategies, namely utilizing online learning (online), off-network learning (offline), and a combination of online and offline learning (Hidayati, 2016).

Online learning is a learning process that is the same as face-to-face learning. Online learning uses all the components in face-to-face learning, and it's just that the media that distinguishes it is face-to-face using room facilities, while online uses cyberspace. Online learning is carried out using electronic devices and internet networks. In its implementation for teachers and students, several essential things must be carried out correctly (Stodel et al., 2006). Such as the ability of teachers and students to Computer Information Technology (ICT), the availability of simple and effective teaching materials, laptops/gadgets/pc, a good internet network. Most important of all is the ability of parents to meet these online learning needs. So, all these components will influence each other towards the optimal implementation of online learning (Durlak et al., 2011).

Offline learning is used in learning Indonesian as a variant of the implementation of learning. Offline learning does not require components as complete as online learning. It takes a few textbooks and assignments students have to do at home. Furthermore, PJJ is also used online and offline or called a combination. The most frequently used by teachers is learning with a combination of online and offline strategies (Suartama et al., 2019). 
The three learning strategies during the pandemic are designed and possible in a Learning Implementation Plan (RPP). RPP is a preparatory step from the teacher before starting learning. The lesson plans are made following the competencies stipulated in the Minister of Education and Culture Regulation No. 37 of 2018 concerning Basic Competencies of Indonesian language subjects, which are the minimum skills that students must possess in and after learning the Indonesian language (Giusti et al., 2017). So, at a minimum, teachers must facilitate students to achieve the minimum competencies set by the curriculum. If possible, you can develop it beyond the minimum competency (Albanese et al., 2010).

Indonesian language learning needs to be appropriately implemented, regardless of the strategy used in the implementation process. Psychologically Indonesian has a vital role in the development of students, both intellectually, emotionally, socially, culturally, all of which help students learn the material in various subjects (Sobri et al., 2019). Using language, students will express their ideas, opinions, knowledge in writing and orally. Through learning Indonesian, students can communicate their ideas and expertise properly and correctly (Zaim, 2017).

Related to the vital role of Indonesian, learning Indonesian is text-based learning. Intext learning materials are connected with various life phenomena, coupled with science in other fields that students at school also study. Therefore, the text becomes a medium for language and communication and conveys ideas in all areas (Chuntala, 2019). So in learning Indonesian, the text becomes the output for students. Of course, the output in the form of text made by students begins with strengthening their knowledge and understanding of the text, then ends with the skill of making texts according to the context in writing and orally (Widiati \& Cahyono, 2016).

Observing learning during the COVID-19 pandemic, the minimum competence that must be achieved is difficult to achieve. Learning during this pandemic has become ineffective. Learning behavior is neglected with the dominance of more attractive applications to students on their gadgets (Maunder et al., 2003). Some of them cannot participate in learning optimally due to the limited facilities and infrastructure that support learning during this COVID-19 period. The limited ability of parents is also a trigger for the ineffectiveness of the learning carried out (Lundberg \& Pollak, 2007).

In learning Indonesian, these problems become more complex. Learning Indonesian is difficult for students to learn and understand. Competencies that are compiled are not appropriately achieved. Learning tends only to provide information and provide knowledge (Kadir \& Satriawati, 2017). From several interviews with Indonesian language teachers, it was stated that it was challenging to teach Indonesian. Most students cannot achieve learning indicators, even easier ones (Asrial et al., 2019).

The competencies that students in language learning must possess are contained in the Indonesian language syllabus, namely (1) speaking Indonesian with an emphasis on listening, reading, viewing, speaking, and writing skills; (2) developing listening, reading, viewing, speaking, and writing skills through text media. The text is the embodiment of social activities and has a social purpose. The characteristics accommodate the achievement of this goal: the way of expressing social goals (which is called the rhetorical structure), the choice of words that follow the objectives, and the grammar that follows the purpose of communication; and (3) communication in written, oral, or multimodal form (i.e. text that combines language and 
other communication methods/media such as visual, sound, or verbal as presented in a film or computer presentation) (Asrial et al., 2019).

The need to evaluate the implementation of Indonesian language learning during the COVID-19 pandemic is expected to provide an overview of the competencies possessed by students during this pandemic. This description will contribute to the idea that students have a middle competence in Indonesian language skills. For teachers, these findings can provide thoughts on improving and refining students' competencies and an overview for choosing the right strategy to start learning in the following semester. For students, it can be used as a benchmark for the competencies they already have.

\section{B. LITERATURE REVIEW}

\section{Indonesian Language}

Understanding language is a system of arbitrary sound symbols used by members of social groups to work together, communicate, and identify themselves. Language is a symbol system. A symbol is a sign used by a social group based on an agreement, and to understand it must be studied (Stokoe, 2005). A sign is a thing or object that represents something. Because it is a symbol and represents something, language is meaningful, meaning that language is related to all aspects of life and the environment around the people who use it (Perera et al., 2013).

Humans use language in all activities of life. Thus, language is an essential thing in human life. The notion of language is that language is the most important thing for human life as a system of sound symbols used to communicate, interact, work together, and identify itself in everyday life (Fillmore, 1976). The position of the Indonesian language is now increasingly solid as a vehicle for communication, both in social relationships and in formal relationships. Indonesian is the Malay language used as the official language of the Republic of Indonesia and the language of the Indonesian nation's unity (Tenner, 1967).

Indonesian language learning must be given in all formal educational institutions. Indonesian is a subject that teaches students to communicate appropriately and correctly. This communication can be done orally and in writing (Saddhono et al., 2019). Indonesian language learning must help students develop language skills in the environment to communicate and absorb various values and knowledge learned. Through language, students can learn moral or religious values and social values that apply in society (Wekke \& Hamid, 2013).

Based on the notions that experts have put forward regarding education and understanding of language, it can be concluded that the idea of Indonesian language education is a system of sound symbols used by a society to communicate, interact, work together, and identify themselves in everyday life as an effort to guide and direct the potential of human life in the form of the ability to learn, so that changes will occur in a person.

\section{METHOD}

This research will be carried out using a qualitative approach as the research method. The data used are obtained through the results of previous studies and studies that have been carried out previously and are still related to this research. The data that has been successfully collected will be analyzed to obtain the expected results. 


\section{RESULT AND DISCUSSION}

1. Preparation for the implementation of Indonesian language learning during the Covid-19 pandemic

Learning during the COVID-19 pandemic was initially carried out with great confusion by the teacher. Although 4 Ministerial Decrees have been issued regarding the implementation of learning in the Pandemic, technically, teachers' performance has not yet been received the right way. Many problems arise, such as the limited ability of teachers to use ICT, starting learning with students who are not known at all, lack of facilities and infrastructure, and so on. However, learning must still be carried out.

The first thing the teacher does is make learning preparations following the guidelines for implementing learning during the covid 19 pandemic. Preparation is not just creating a Learning Implementation Plan, but preparation must begin by understanding the guidelines set by the government. This guide is the direction of how a lesson is planned by considering all aspects, both teachers, students, learning strategies and their management, materials and resources used, competencies to be taught, availability of facilities and infrastructure, and most importantly, the condition of the area or zone of areas exposed to COVID-19.

Therefore, the teacher prepares himself by designing learning. How teachers design learning is contained in the guidelines for implementing learning during the COVID-19 pandemic issued by the Ministry of Religion, known as the Emergency Curriculum. The Emergency Curriculum includes guidelines on the Emergency Curriculum Concept, Learning in an emergency, learning steps during an emergency, and assessment of learning outcomes. Based on the questionnaire distributed to respondents, information was obtained that the understanding of the emergency curriculum was not evenly distributed.

Not all teachers understand well the guidelines for implementing the Emergency Curriculum. This shows that most teachers do not understand the main objectives of learning during an emergency. Then the teacher has made preparations to implement learning in the lesson plan. RPP is made following the Emergency Curriculum guidelines, namely RPP in online, offline, and combination forms. The RPP made is more dominant in the online and offline RPP. For its implementation, more use of online RPP. The lesson plans are made using various learning materials from multiple sources, namely, $40 \%$ of the materials taken by the teacher from multiple sources. This makes it easier for teachers and students to develop their insight into learning Indonesian.

\section{Implementation of Indonesian Language Learning in the Covid-19 Pandemic Period}

The implementation of learning during the COVID-19 pandemic has referred to the guidelines for implementing the emergency curriculum and Permendikbud No 37 of 2018. Both regulations are implemented in learning. However, there are some polemics in its implementation. This polemic in Indonesian language learning has not been carried out optimally. Even though it has implemented references following regulations, the designed learning activities have not been fully achieved. The data obtained that $70 \%$ are almost following the lesson plans designed to implement learning. This indicates that there are still parts of the RPP that have not been implemented optimally. Based on the teacher's answer, the part that was not implemented following the lesson plans was learning activities. Some of the 
causes are the unevenness of participants having internet quota facilities to participate in online learning, the limited-time set for online learning, and not smooth communication because students do not respond to learning.

Based on an open questionnaire given to respondents, information was obtained that students' low response and learning activities were caused by difficulty understanding learning materials delivered online. Learning materials prepared by the teacher are not studied optimally by students at home. The leading cause is the divided focus of student learning due to various applications on gadgets that affect their learning activities. Furthermore, the use of mobile phones that take turns in the same house is also the cause of the inadequate response of participants in learning activities.

Another cause is the limitation of parental supervision at home due to busy work and lack of understanding in guiding children in learning. Furthermore, all knowledge material is taught to students. Although completeness is not optimal, the dominance of KD knowledge is more given to students.

\section{Indonesian Language Learning Outcomes}

Student learning outcomes represent the success or failure of the learning process carried out. Student learning outcomes can be used to evaluate the implementation of the learning process. The achievement of learning outcomes in the KD knowledge of Indonesian language learning can be complete. Mastery learning is marked if the mastery of the substance of a KD is the level of proficiency of students over a certain KD. In general, students achieve mastery of learning and also, in general, students have mastered the competence of at least $75 \%$ of the set. The ability of KD knowledge is influenced by the implementation of learning that tends to teach KD knowledge. Learning KD knowledge achieved by students is higher than the achievement of KD Skills. After mastering their understanding, the KD knowledge of $50 \%$ of students is above average (75\%).

Then students make their texts according to what is understood from the content knowledge about the structure of a text and examples of texts they know. Of course, with limited time and media, the textbooks made by students have been collected. The existing limitations make the teacher not maximal in teaching participants to be skilled at writing texts as they should. This shows that learning to write texts has not been implemented well.

\section{Discussion on the Implementation of Indonesian Language Learning During the Covid-19 Pandemic}

The implementation of Indonesian language learning has become a spotlight in education. Many obstacles were found in the implementation of learning. The change from face-to-face learning to online, offline, and combined learning has become a new habit that is very problematic and dilemmatic in its implementation. This change has an impact on the demands of teachers' educational competence. Teachers who are usually unfamiliar with devices and laptops in carrying out learning become teachers who in urgent need must master various applications that support online learning. Students who were initially limited in using gadgets became free without limits in using devices, and in fact, there were no days without gadgets. All of this has an impact on learning. Both teachers and students become familiar with this. 
The implementation of Indonesian language learning during the COVID-19 pandemic refers to the guidelines set by the government through the Decree of the four Ministers and the Decree of the Director-General of Education No. 2197 of 2020 concerning guidelines for the implementation of learning. In this regulation, the implementation of learning is adjusted to the zone set by the task force regarding the spread of the coronavirus. The red area stipulates that learning is carried out from home with the Distance Learning (PJJ) system. This PJJ is carried out with due regard to students' learning rights, which the state guarantees. As stated in General \& Islam, all students must continue to receive education and learning services from schools during an emergency.

Therefore, the importance of teachers' understanding of the curriculum and the goals set by the curriculum must be done, especially the curriculum that is being implemented at that time. Teachers need to understand the curriculum because the curriculum is an educational program that contains various teaching materials and learning experiences that are programmed, planned and designed systemically based on applicable norms used as guidelines in the learning process for education staff and students to achieve educational goals. Teachers play an essential role in the achievement of educational goals.

In connection with implementing the emergency curriculum that was imposed during the COVID-19 pandemic, teachers still did not understand the emergency curriculum well based on the data obtained. In the emergency curriculum, learning does not only meet the demands of competence (KI-KD) in the curriculum. Still, it emphasizes character development, noble character, ubudiyah and student independence. This does not appear to be the primary choice for teachers when there is a choice of dominant competencies to be learned during an emergency. In general, teachers prioritize knowledge competencies to be achieved in the implementation of learning compared to other competencies.

If the teacher designs the curriculum following the emergency curriculum guidelines by prioritizing character development, noble character, ubudiyah and student independence, the participants have been trained to be responsible for the learning they follow. Of course, students will take part in learning according to what was planned by the teacher because responsibility does not just come but needs to be used in everyday life. As stated by Yaumi, learning responsibilities need to be owned and inculcated in everyday life (Septiadi et al., 2019). So it can be understood the teacher plays a central role in curriculum implementation. For this reason, understanding the curriculum is the first step before the teacher implements and implements the curriculum itself.

Preparing the implementation of learning in lesson plans is the teacher's first step in implementing the curriculum. RPP is designed following the direction and objectives of the curriculum. RPP in the emergency curriculum is RPP specially designed in an emergency. RPP is designed and structured according to how the learning strategy is implemented. In the emergency curriculum, which was carried out during the COVID-19 pandemic, the teacher correctly designed it. The RPP made is following the PJJ strategy. RPP for PJJ, apart from referring to learning strategies in the emergency period, also relates to the principles of preparing RPP PJJ.

The teacher must understand the concept of PJJ before making lesson plans. As stated by Hurd that PJJ is a learning activity, it describes learning activities where students and teachers are at a physical distance from each other (Hamid et al., 2015). In this study, students 
learn independently. In this context, teachers need to understand how with PJJ, students can learn well to achieve knowledge, skills and, more importantly, attitudinal competencies. If the lesson plans are prepared by taking into account the competencies that students must complete, the lesson plans will be designed according to the needs of students so that they can learn independently. So, distance limitations time constraints that cause problems can be minimized. Therefore, learning activities that tend to be inconsistent with the implementation of learning will not be found in PJJ.

In essence, PJJ is learning describing learning activities in which students and teachers are at a physical distance and do not face to face. PJJ can be done anywhere and anytime by students. Learners independently determine their progress in learning. Teachers need to understand the concept of PJJ about the obstacles and problems to teach students better (Mohd Nadzar, 2013).

The RPPPJJ, which is designed by taking into account the conditions and situations and the direction of the emergency curriculum objectives, is then implemented in the learning process in the form of distance learning. The implementation of learning seen in research findings tends to teach KD knowledge more. Of course, this is not in line as expected in the guidelines for implementing the Emergency Curriculum. This means that there is a neglected competence, namely attitude competence. This abandonment was not something that was done intentionally. The limitations of teachers in understanding and preparing for learning under a pandemic situation make learning not planned comprehensively. At the beginning of the lesson, the teacher had anxiety and confusion about implementing PJJ.

Indonesian language learning aims to form students able to communicate in writing and orally using the suitable and correct language. This language ability is text-based. Text is a complete language unit socially and contextually. The same opinion was also expressed by Hartoko and Rahmanto, that the text is an orderly sequence of several sentences produced and interpreted as a whole that is interconnected (Sri et al., 2016). Here, the text is not only in written form but can also be in spoken form. Learning Indonesian during the pandemic is dominated by learning knowledge. Of course, there is still a lot that needs to be addressed to get students' Indonesian language competence following the demands of the curriculum.

Furthermore, student learning outcomes are the impact of the teacher's learning preparation and the implementation of learning carried out by students and teachers. The implementation of Indonesian language learning during the COVID-19 pandemic left a history of the many problems faced by teachers and students. Learning and learning is still a must, even in any condition. Education should not be neglected and left behind because a country will be dignified if education is always good. Therefore, the government guarantees the right of every citizen to obtain an education.

\section{E. CONCLUSION}

The implementation of Indonesian language learning during the COVID-19 pandemic is carried out based on regulations set by the government, namely the Decree of the 4 Ministers and the Decree of the Director-General of Education No. 2197 of 2020 regarding the implementation of learning in the emergency period. The guide creates an emergency curriculum. The above regulation is a curriculum conditioned and adapted to the country exposed to covid 19. This emergency curriculum is a reference in the implementation of 
learning during the covid 19 pandemic, likewise with learning Indonesian. Indonesian language learning has followed these guidelines, although there are some obstacles and inadequacies in its implementation. Not all teachers understand well the directions and learning objectives set in the emergency curriculum. In the implementation of the KD learning process, knowledge is completely learned. It can be seen that students achieve KD knowledge learning outcomes above $75 \%$. However, for Indonesian language learning outcomes, KD skills have not been completed. In general, students do not have good skills in writing texts.

\section{REFERENCES}

Al Arif, A. (2017). Legal status of maximum sustainable yield concept in international fisheries law and its adoption in the marine fisheries regime of Bangladesh: a critical analysis. The International Journal of Marine and Coastal Law, 32(3), 544-569.

Albanese, M. A., Mejicano, G., Anderson, W. M., \& Gruppen, L. (2010). Building a competency-based curriculum: the agony and the ecstasy. Advances in Health Sciences Education, 15(3), 439-454.

Asrial, A., Syahrial, S., Kurniawan, D. A., Subandiyo, M., \& Amalina, N. (2019). Exploring Obstacles in Language Learning among Prospective Primary School Teacher. International Journal of Evaluation and Research in Education, 8(2), 249254.

Chuntala, A. D. W. (2019). Saintific approach in 21st century learning in indonesian language learning vocational school of pharmacy. International Journal of Active Learning, 4(2), $71-77$.

Durlak, J. A., Weissberg, R. P., Dymnicki, A. B., Taylor, R. D., \& Schellinger, K. B. (2011). The impact of enhancing students' social and emotional learning: A meta-analysis of school-based universal interventions. Child development, 82(1), 405-432.

Fillmore, C. J. (1976, October). Frame semantics and the nature of language. In Annals of the New York Academy of Sciences: Conference on the origin and development of language and speech (Vol. 280, No. 1, pp. 20-32).

Giusti, A., Perra, A., \& Lombardo, F. (2017). The experience of a nationwide Community of Practice to set up Regional Prevention Plans in Italy. Health Research Policy and Systems, 15(1), 1-10.

Hamid, S., Waycott, J., Kurnia, S., \& Chang, S. (2015). Understanding students' perceptions of the benefits of online social networking use for teaching and learning. The Internet and higher education, 26, 1-9.

Hidayati, T. (2016). Integrating ICT in English language teaching and learning in Indonesia. JEELS (Journal of English Education and Linguistics Studies), 3(1).

Kadir, L., \& Satriawati, G. (2017). The implementation of open-inquiry approach to improve students' learning activities, responses, and mathematical creative thinking skills. Journal on Mathematics Education, 8(1), 103-114.

Lundberg, S., \& Pollak, R. A. (2007). The American family and family economics. Journal of Economic Perspectives, 21(2), 3-26.

Maunder, R., Hunter, J., Vincent, L., Bennett, J., Peladeau, N., Leszcz, M., ... \& Mazzulli, T. (2003). The immediate psychological and occupational impact of the 2003 SARS outbreak in a teaching hospital. Cmaj, 168(10), 1245-1251.

Mohd Nadzar, F. (2013). Evaluating library collections and support services for distance learning programme: a study of e-PJJ students' perceptions of PTAR UiTM, Malaysia/Halimatun Saadiah Roselley and Fuziah Mohd Nadzar. Journal of Information and Knowledge Management (JIKM), 3(1), 63-74. 
Perera, C., Zaslavsky, A., Christen, P., \& Georgakopoulos, D. (2013). Context aware computing for the internet of things: A survey. IEEE communications surveys \& tutorials, 16(1), 414-454.

Saddhono, K., Sudarsana, I. K., \& Iskandar, A. (2019, November). Implementation of Indonesian Language the learning Based on Information and Communication Technology in Improving Senior High School Students' Achievement in Surakarta. In Journal of Physics: Conference Series (Vol. 1254, No. 1, p. 012059). IOP Publishing.

Septiadi, H. N., \& Andayani \& Wardani, N. E. (2019). Planting Base Value of Hardworking Character Education through Ulid Novel. Budapest International Research in Linguistics and Education Sciences (BirLE) Journal, 36-44.

Sobri, K. M., Hanum, F., Zulnaidi, H., \& Ahmad, A. R. (2019). A comparative study of school environment for students' skills development in Malaysia and Indonesia. Kasetsart Journal of Social Sciences, 40(1), 149-154.

Sri, B., Herman, J. W., St, Y. S., \& Muhammad, R. (2016). The Text-Based Indonesian to Stimulate Achievement and Motivation (A Textbook for the Seventh Graders of Junior High Schools). International Journal of Science and Research (IJSR), 5(11), 15961599.

Stodel, E. J., Thompson, T. L., \& MacDonald, C. J. (2006). Learners' perspectives on what is missing from online learning: Interpretations through the community of inquiry framework. International Review of Research in Open and Distributed Learning, 7(3), $1-24$.

Stokoe Jr, W. C. (2005). Sign language structure: An outline of the visual communication systems of the American deaf. Journal of deaf studies and deaf education, 10(1), 3-37.

Suartama, I. K., Setyosari, P., \& Ulfa, S. (2019). Development of an instructional design model for mobile blended learning in higher education. International Journal of Emerging Technologies in Learning, 14(16).

Tanner, N. (1967). Speech and society among the Indonesian elite, a case study of a multilingual community. Anthropological linguistics, 15-40.

Wekke, I. S., \& Hamid, S. (2013). Technology on language teaching and learning: a research on Indonesian pesantren. Procedia-Social and Behavioral Sciences, 83, 585-589.

Widiati, U., \& Cahyono, B. Y. (2016). The teaching of EFL writing in the Indonesian context: The state of the art. Jurnal Ilmu Pendidikan, 13(3).

Zaim, M. (2017). Implementing scientific approach to teach English at senior high school in Indonesia. Asian Social Science, 13(2), 33-40. 